\title{
Countryside Settlement and its Transformations in Case of Moravian- Silesian Beskids and its Foothills
}

\section{Venkovské osídlení a jeho transformace na př́kladu Moravskoslezských Beskyd a jejich podhưř́}

Jan Kraut, jan.kraut@gmail.com

Ústav památkové péče, Fakulta architektury, Vysoké učení technické v Brně školitel: prof. Ing. arch. Koutný Jan, CSc.

\begin{abstract}
For last two centuries many changes has been passing through czech countryside. This features are different from region to region and we can see its results on settlement, landscape or society transformation. The paper is mapping ths features on countryside settlement in east part of hte Czech republic. This region was colonized as last part of the Czech republic and it has a lot of specifics. That's why there are specific settlement structure and landscape using which are destroyed by large industrialization and urbanization. The charakter, continuity and qualities of area are hard to identify and to interpret.
\end{abstract}

KEYWORDS: Moravian-Silesian Beskids; countryside settlement; pastoralism; industrialization; urbanization

\footnotetext{
ABSTRAKT: Český venkov v uplynulých dvou stoletích prošel řadou změn, ty se v tomto různorodém prostoru mnohdy liší - jak vlivem na podobu prostoru, tak mírou transformace společnosti. Př́spěvek mapuje dopady těchto změn na situaci venkovského osídlení v severovýchodní části republiky. Toto území patří mezi nejpozději osídlené krajiny naší republiky s řadou specifik, ta vedla k jedinečné podobě osídlení, kterou následně velmi narušil průmysl a překotná urbanizace. Charakter, kontinuitu a kvality prostředí je zde proto obtížné identifikovat charakter, kontinuitu a kvality prostředí a správně je interpretovat.
} 
KLÍČOVÁ SLOVA: Moravskoslezské Beskydy; venkovské osídlení; pastevectví; industrializace; urbanizace

\section{Vymezení popisované oblasti}

Popisovaná oblast se nachází v jižní části Moravskoslezského kraje. Území je možné vymezit česko-polskou a česko-slovenskou hranicí a ve ,vnitrozemí městy Rožnov pod Radhoštěm, Frenštát pod Radhoštěm, Frýdek-Místek a Třinec.

\section{Př́ŕodní a krajinná charakteristika oblasti}

Území České republiky je tvořeno dvěma základními geologickými jednotkami území vrásnění hercynského a alpínsko-himálajského. Odlišný geologický původ a stáří Beskyd odlišuje oblast od zbytku republiky. Popisovaný region leží cele v Carpaticu, v prostoru hor a na jejich úpatí, kde nacházíme relativně výrazně převýšené zalesněné horské masívy (max. převýšení 1000 m) s úzkými údolími a minimem úrodných rovin s černozeměmi, jelikož i podhůř́i jsou částečně zvrásněna. Kvůli značné hornatosti se toto přirozeně zalesněné území nachází ve 3 . vegetačním stupni nebo vyšších polohách. Tím spolu s reliéfem vykazuje horší obdělávatelnost a úrodnost než tradiční sídelní oblasti Velkou část území dnes tvoří CHKO Beskydy, kde jsou dominantní lesní porosty s enklávami starých vesnic. Odlesněné podhůří s hustou sídelní strukturou je silně urbanizováno. Krajinný ráz určovaný v minulosti zemědělstvím, a zejména pastevectvím je v současnosti výrazně pozměňován zalesňováním, industrializací a suburbanizací.

\section{Osídlování regionu}

Oblast byla kolonizována jako jedna z posledních v České republice. O počátku souvislého osídlování, prozatím pouze v podhůří, můžeme hovořit až v souvislosti s populační expanzí a vrcholně středověkou kolonizací zejména za posledních Přemyslovců. Do této etapy kolonizace spadá severozápadní okraj vymezené oblasti (Frýdek-Místek, Frenštát p. R., Frýdlant nad Ostravicí a okolní vesnice).

Novověké osídlování pokračovalo postupným rozšiřováním stávajícího osídlení dále do údolí a mýcením pasek na úpatí hor či procesem tzv. valašské kolonizace horských oblastí. Až na začátku 18. století proniklo osídlení v podobě prvních osad i do nejnepřístupnějších oblastí. Proces rozšiřování osídlení pokračoval až do 2 . sv. války. Během německého tažení proti partyzánům byla vybita a vypálena řada samot a osad v horách a po válce akcelerovalo opouštění hor (a jejich přeměna na rekreační oblasti). 


\section{Historické typy vsí}

Původní osídlení a půdorysná struktura vsí v oblasti pak vykazují znaky a typy známé ze zbytku ČR, ale také prvky spojené s horským salašnictvím. Tyto vlivy a jejich kombinace a přizpůsobování lokálním poměrům vytvořily řadu krajových specifik v podobě vsí a tím i odlišné impulzy pro soudobý vývoj.

Vsi soustředěné (uliční a návesní ves, okrouhlice, ulicovka): Tyto vsi se zřetelně a těsně vymezenou strukturou jsou typické pro starší osídlení, v popisované oblasti nejsou zastoupeny.

Vsi s rozvolněným půdorysem (řadová, lánová, řetězová valašská a řetězová goralská ves): Vsi svým vznikem spadající do pozdně středověké kolonizace a kolonizace raného novověku s rozvolněným půdorysem, avšak se stále čitelným prostorovým předpisem jejich uspořádání kolem průběžné osy.

Vsi př́rodní a rozptýlené (shluková, hromadná a dvorcová ves): Některé vsi starší a zejména velké množství novověkých vsí zakládaných na lesních pozemcích s nepravidelným půdorysem. Dvorcové vsi jsou přechodem mezi vsí a samotou. Tvoří je zpravidla několik samostatných usedlostí s dvorci (polnost, zahrada, ohrada).

Samoty: Typ osídlení, který není možno plnohodnotně nazývat vsí, jelikož se jedná o jedinou usedlost (či několik usedlostí) s dvorcem uprostřed lesů.

Salaš: Zpravidla jediné provizorní stavení a ohrada. Avšak i tato, ve vyšších polohách pouze sezónní obydlí tvořila centrum velkých ploch pastvin.

\section{Organizace obhospodařované krajiny}

Přírodní podmínky, topografie a způsob hospodaření se také promítly do využití krajiny a organizace plužin. Níže uvedené rozdělení je doplněno o některé lokální odlišnosti a adaptace.

Plužina úseková, dělená úseková: Tyto typy plužiny rozšiřené po celé republice jsou $\mathrm{v}$ popisované oblasti zastoupeny ve specifické poloze u novověkých nesoustředěných zejména dvorcových vsí v hornatých oblastech.

Plužina tratová: Tento typ v regionu prakticky nenalezneme, jelikož je úzce spjat se soustředěnými vesnicemi a mírným průběhem reliéfu. 
Plužina délková, záhumenicová, lánová: Tyto typy plužin jsou typické pro vrcholně středověkou kolonizaci a v našem př́padě i pro novověkou kolonizaci podhorských oblastí, avšak v měřítku přizpůsobeném řadovým a lánovým vsím.

Moderní scelená plužina: I kvůli složitější topografii v oblasti často dochází k propojování polí rozdílných kvalit a stanovište, vyšší míře znehodnocování půdy a eroze, snížení biodiverzity a narušení přirozené hierarchie a tras v území.

Hrazená pole: Typ uspořádání pozemků jednotlivých usedlostí např. u dvorcových vsí nebo ve svažitých oblastech. Tvar a velikost jednotlivých parcel jsou přizpůsobeny průběhu terénu. Tyto parcely jsou navíc ohrazeny kamennými zídkami a mezemi (remízy).

Pastviny, pastevní les, lesní pěstování obilovin: Tyto většinou minoritní způsoby využití krajiny zde hrají mnohdy dominantní roli a určují podobu osídlení. Pastviny byly jednak součástí dvorců jednotlivých usedlostí a jednak obklopovaly vsi, zasahovaly do lesů a táhly se po hřebenech hor.

\section{Hlavní novodobé transformační vlivy a jejich dopady na sídelní a kra- jinnou strukturu oblasti}

Někdejší převážně venkovské osídlení se v průběhu staletí plynule vyvíjelo postupným osídlováním pohraničních hvozdů. Již od třicetileté války hrál v území roli i průmysl, zejména hutě, popř. papírny. Př́íchod průmyslu zpočátku znamenal pouze nepatrné změny (zvýšená těžba dřeva), avšak již od počátku 19. století hrál natolik významnou roli, že ovlivňoval i širší okolí a celé osídlení. Postupná industrializace akcelerovala po roce 1945 a byla spojena s masivním opouštěním lesních osad a př́ílivem nových obyvatel z okolních regionů. Některé vesnice zanikaly, některá dřívější centra se ocitla mimo dění, a naopak některým vesnicím se několikanásobně zvedl počet obyvatel a vznikaly i vesnice nové. Takto došlo (někdy již v 19. století) ke značným disproporcím ve struktuře osídlení i v podobě samotných sídel.

Poválečná politicko-hospodářská politika směrovala region ryze k těžkému průmyslu a těžbě uhlí, podporovala opouštění horských osad a potírala původní salašnictví. $\mathrm{V}$ důsledku prudkého př́livu obyvatel se severní Morava stala v rámci ČR výraznou urbanizační oblastí, kde se venkovské prostředí změnilo na prostředí městské, a to mnohdy až k samé hranici CHKO Beskydy.

Značnými změnami prošla i samotná krajina (zemědělská i lesní) - industrializací a urbanizací, ale zejména kolektivizací. Dopady vyvlastňování půdy, zřizování družstev, reorganizace plužin, vznik nadměrně velkých ploch jednotlivých polí či ne- 
vhodná plodinová skladba jsou všeobecně známé negativním účinkem na krajinu. A to $\mathrm{v}$ projevech jak hospodářských, tak ekologických, historických a estetických. Každý typ krajiny a plužiny však na tyto jevy reaguje rozdílně. Např́ílad při neznalém scelování úsekových plužin a rušení odvěkých mezí, teras a cest v oblasti se složitějším reliéfem a velkým úhrnem srážek se mohou negativní dopady projevit se značnou intenzitou.

Vývoj po roce 1989 a současná situace přinesly řadu pozitivních změn, zejména na poli ochrany životního prostředí a hospodářství, kde bylo upuštěno od monopolu těžkého průmyslu. Velké množství obyvatel opustilo průmysl a region se snaží najít další ekonomický směr. Hovoříme nyní o oblasti, kde se nacházejí dvě základní matrice: lesní horské oblasti s rekreačním využitím a silně urbanizované postindustriální území na jejich úpatí. Třetí, menšinovou kategorií jsou postagrární vesnice mimo urbanizační osy. Následkem značné urbanizační vlny uplynulého století došlo k narušení tradiční sídelní struktury a rozvolněná sídla a dvorcové usedlosti charakteristické pro tento region daly vzniknout „sídelní kaši“ ještě před současnou vlnou suburbanizace, která je v oblasti velmi výrazná.

Tradiční venkovský způsob života, který se v mnoha oblastech ČR ještě aspoň částečně udržel a utváří tamní prostředí a krajinu, z popisované oblasti již téměř vymizel. Vymizela tím i pomyslná možnost zachytit způsob utváření osídlení, který je pro tuto oblast přirozený, a navázat na něj. Situaci výrazně ztěžuje velké množství přistěhovalců bez konkrétních vazeb na prostředí, převaha městského obyvatelstva i na vesnicích a problematika hledání soudobých spojnic s původní obživou obyvatelstva.

\section{Prameny}

CULEK, M. [ed.] et al.,1996. Biogeografické členění české republiky. Enigma Praha. HÉDL, Radim, SZABÓ, Péter, RIEDL, Vladan, KOPECKÝ, Martin, 2011. Tradiční lesní hospodaření ve střední Evropě II. Lesy jako ekosystém, Živa, Praha: AV ČR; 58(3)

LÖW, Jiř́i, MÍCHAL Igor. 2003. Krajinný ráz. Kostelec nad Černými lesy: Lesnická práce. ISBN 80-86386-27-9.

LÖW, J. et al., 2005. Typologie české krajiny. In: Projekt VaV/640/01/03 Program biosféra. MS. LÖW \& spol., s.r.o. Brno.

MANA, Vladimír, 2007. Krajinný ráz [poznámky a náměty k jeho hodnocení a k posuzování vlivu záměrů] Praha.

MORAVSKOSLEZSKÝ KRAJ. ZÚR MSK a přidružené dokumenty a př́lohy

ROMPORTL, Dušan, 2009.Typologie krajiny České republiky. Praha: Univerzita 
Karlova v Praze. Př́rodovědecká fakulta. Disertační práce. Vedoucí práce Zdeněk Lipský.

ŠTIKA, Jaroslav, 2009. Valaši a Valašsko, O původu Valachů, valašské kolonizaci, vzniku a historii moravského Valašska a také o karpatských salaších. Rožnov p. R.: Valašský muzejní a národopisný spolek. ISBN 978-80-254-6131-0.

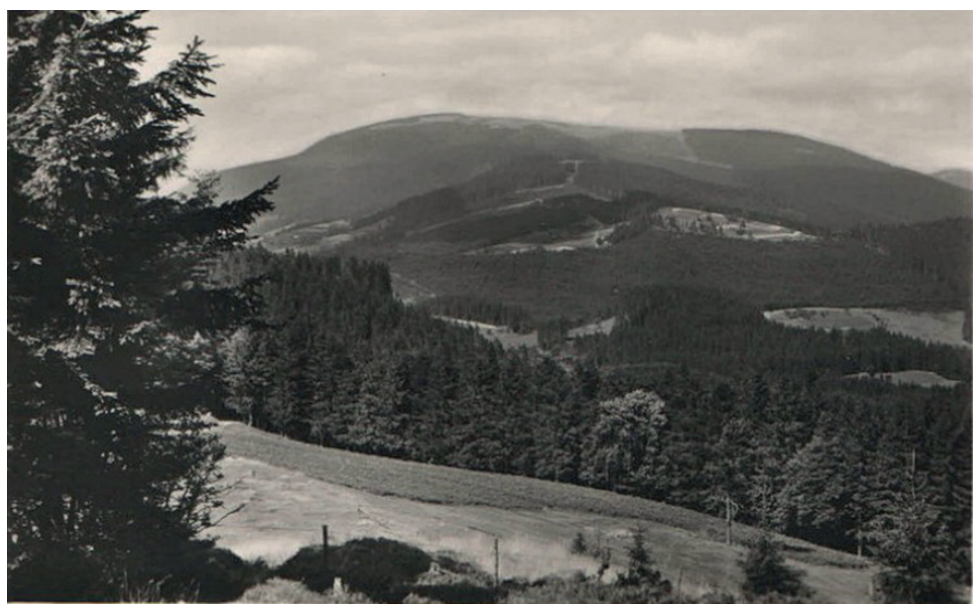

Obr. 1. Horské osídlení - pohled z pastvin osady Bílý Kříž na jednotlivé samoty v lesích s velkou pastvinou na hřebenu hory Travný.,historická pohlednice, (Zdroj: orbitakpostcard.cz)

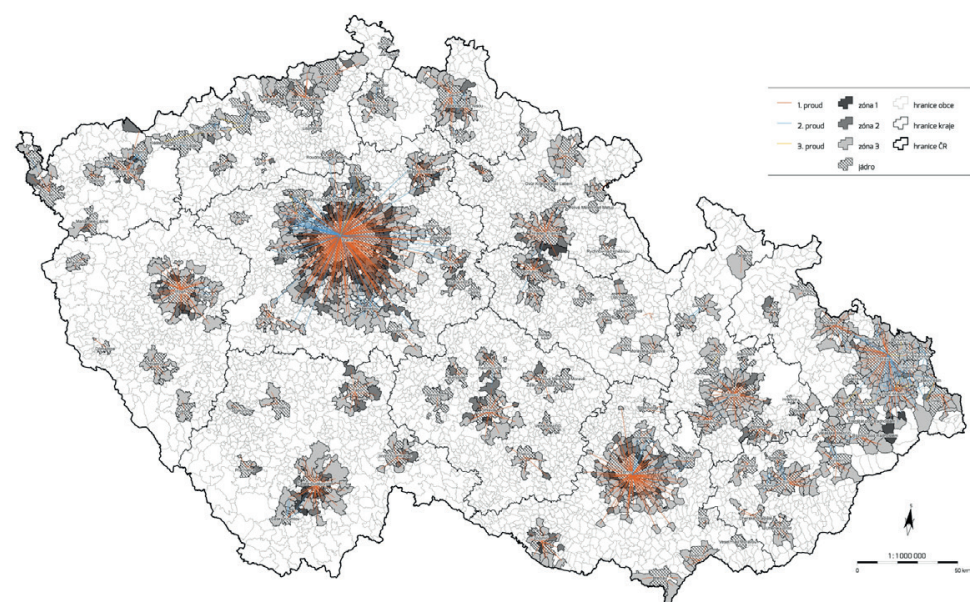

Obr. 2. Zóny rezidenční suburbanizace, 2010 (Zdroj: atlas obyvatelstva) 